\title{
The Impact of the Enrollment Zoning System on the Educational Quality of Vocational Secondary Schools
}

\author{
Istanto Wahyu Djatmiko ${ }^{1 *}$, Samsul Hadi ${ }^{1}$, Muh. Asriadi AM $^{2}$
}

\author{
${ }^{1}$ Department of Electrical Engineering Education, Universitas Negeri Yogyakarta, Indonesia \\ ${ }^{2}$ Department of Educational Research and Evaluation, Universitas Negeri Yogyakarta, Indonesia \\ *Corresponding author. Email: istanto_wj@uny.ac.id
}

\begin{abstract}
Enrollment zoning system policy is one of the benchmarks for equity in distribution and improvement of education quality in Indonesia. This study aims were to determine the impact of the enrollment zoning system on the learning quality of vocational secondary schools (VSSs) in Special Region of Yogyakarta. This study was carried out with a descriptive research approach. The subjects were determined purposive non-probability sampling based on regency area, school status, and school accreditation category as many as 15 principals and 75 teachers of VSSs in Special Region of Yogyakarta. The study instruments were a questionnaire consisting of four aspects, including the school's organization and governance, the learning quality, the student's competency, and the teaching competency aspects. The coefficients of the questionnaire validity test results for each aspect were known to be 0.90 to $0.95,0.89$ to 0.94 , 0.85 to 0.96 , and 0.75 to 0.83 , while the reliability coefficients were $0.98,0.96,0.96$, and 0.91 respectively. Data were analyzed by multivariate analysis of variance approach. The results of the study show that there are significant impacts of the enrollment zoning system on the learning quality at VSSs in Special Region of Yogyakarta in terms of four aspects with the order of each aspect as follows: $10.9 \%$ on student's competency, $10.6 \%$ on school's organization and governance aspect, $9.3 \%$ on learning quality, and $3.7 \%$ on teaching competencies. From these results can be concluded that the student's competency and the school's organization and governance aspects have a significant impact compared to the other two aspects when carrying out the enrollment zoning system.
\end{abstract}

Keywords: enrollment zoning system, education quality, vocational secondary schools.

\section{INTRODUCTION}

The quality of education in Indonesia is one indicator which shows the Indonesia's human resource development level. Quality education will be able to increase the competitiveness of Indonesian human resources with other countries [1]. To improve the quality of education, it is necessary to start with a strategy to increase the distribution of education in macro and microelements levels. The equitable distribution of education on a microscale in an area is one solution in improving the quality of education in that area [2]. If this is done simultaneously in all regencies in Indonesia, the impact will increase the quality of education at a macro level [3]. Efforts to have equality ini education while ensuring the quality of education, collaboration is needed among various parties such as improving various supporting facilities so the educational process can be expected to run well optimally [4]. There are some factors that can support efforts to equalize education in Indonesia, among others: the quality of teaching staff, education costs, supporting facilities and infrastructure, sister schools, and curriculum [5]. Quality education is a learning process that focuses on students as a whole social, emotional, mental, physical, and cognitive development of each student regardless of gender, race, ethnicity, socioeconomic status, or geographic location [6]. Efforts to improve the quality of education are carried out in the form of teacher training, curriculum improvement, improvement of school facilities and infrastructure, and improvement of school-based management. 
Investigating factors influencing aspects of a quality of education can be seen in teachers, school leaders, school environment, learning facilities, and community in an area around schools [7]. In terms of improving the quality of education in secondary schools, it is necessary to revitalize curriculum, improve learning facilities, and improve school governance [8]. Besides, the attitude and learning method of a teacher in a learning process have always been considered as the two most important things. It means that the ability of a teacher to communicate with students is seen as the most important in ensuring a learning quality at a secondary education level [9], and improving transformation of teaching quality in secondary school level, teachers need incentives, training, and regular workshops.

One of the government's policies in addressing the equal distribution of education quality is done through the enrolment zoning system. This zoning system is not only aimed at increasing the distribution of education but also providing access to quality education and realizing education in schools, families, communities (Education in Three Center) by attending schools in a neighborhood where they life [10]. Thus, the zoning system policy is intended for equal access to education services and equal distribution of national education quality. The zoning system policy, which has been implemented since 2017, is considered strategic to accelerate the distribution of education [11]. This is done to reduce and to eliminate inequality in the quality of education, especially in schools system [12]. This policy was done because so far there has been an imbalance between schools perceived as superior schools or favorite schools and unfavorable schools.

The strategy of an enrollment zoning system to improve the quality of education has begun from Basic Education Level to Secondary Education level for schools that managed under the local government [13]. This enrollment zoning system was carried out as an effort to equalize the quality of education in Indonesia, and for the redistribution of teachers, both in number and quality after performed of the zoning system [14]. In addition, an enrollment zoning system is also used to organize management of schools that excess students capacity, so that schools whose students fewer than a number of schools conduct regrouping those schools [15]. Therefore, an enrollment zoning system is an attempt to prevent the buildup of qualified human resources in a particular area and encourage local governments and communities to participate in the equity of quality of education in those regencies, both equalization of teachers and their teachers' qualification.

Admission of new students at vocational secondary school (VSS) level has an ideal determined by student rankings, mapping the quality of education at VSS level. Acceptance of new students is determined by several zoning paths, achievements, and affirmations. Home radius path, achievement (grade), and acceptance are determined by ranking or student ranking adjusted by the quota of each path of school [16]. Furthermore, the affirmation path is not determined by ranking, but by students with low economic as evidenced by the Smart Indonesian Card. The ranking of the zoning path is determined by the criteria for schools having the same regency as the radius of their house, who will have a great chance of being accepted at that school. Hence, the ranking based on achievement (grades) is determined by the acquisition of grades from the subjects listed in the student's certificate of VSS which will be used as a benchmark for achievement paths to continue to VSS school level [17]. The achievement criteria can be seen from the quality mapping in previous education, namely VSS level. Schools with quality in facilitating students in both learning facilities and infrastructure for 3 years of study will see different results from schools that do not support the learning quality.

In reality, an enrollment zoning system has only been performed using a student's rank. This causes an enrollment process is not ideal causing a polemic in the community about good schools and some complaints from parents. Implementation of an enrollment zoning system at VSS level involved various parties, both schools, students, and parents, which has a negative impact [18]. On the school's side, the zoning system means schools can no longer select students based on the school's criteria or standards that may have been used previously when the zoning system was not applied yet. Due to the lack of school control over these student's inputs, new students generated from the zoning system may lead to the possibility that the input data will be higher or lower rather than new students with a previous enrollment system. Finally, students with good academic abilities or excel in certain subjects will not face challenges when enrolling in certain schools.

Those various problems will have an impact on the quality of education. In addition, an enrollment zoning system policy should be able to perform a school's principals and teachers in improving services and learning systems. However, due to various problems in the real fact during the implementation of the zoning system policy, a school's principals and teachers can only provide services and learning systems according to their school's abilities respectively. The enrollment zoning system has several positive and negative impacts on the equal distribution of educational quality, but the Indonesian government has been attempting to minimize those negative impacts in implementing the enrollment zoning system [19]. Considering those problems, this study aims to determine the differences of the quality of education in the school's organization and governance, the learning quality, student's competency, and teaching competency aspects at VSS level in each regency in Special Region of Yogyakarta as a reflection of the enrollment zoning system policy. 


\section{RESEARCH METHODS}

This study was conducted using a descriptive research approach and carried out from June until August 2021 at 15 VSSs in 5 regencies in the Special Region of Yogyakarta (Bantul Regency, Gunung Kidul Regency, Kulonprogo Regency, and Yogyakarta City). Subjects were determined by purposive nonprobability sampling based on regency area, school's status, and school's accreditation category. The subjects were 15 principals and 75 teachers of VSSs in Special Region of Yogyakarta. The study instrument was developed using questionnaire consist of four aspects, which include the school's organization and governance, the learning quality, the student's competence, and the teaching competence. The coefficients of the questionnaire validity test results for each aspect were known to be 0.90 to $0.95,0.89$ to $0.94,0.85$ to 0.96 , and 0.75 to 0.83 , while the reliability coefficients were $0.98,0.96,0.96$, and 0.91 respectively. Data were analyzed by multivariate analysis of variance approach.

\section{RESULT AND DISCUSSION}

\subsection{Overview of the Quality of Education in Vocational Secondary Schools}

Data on the quality of education is obtained from school's principals and teachers. The quality of education is obtained from VSSs throughout Special Region of Yogyakarta. Four aspects are used to determine the quality of education in Special Region of Yogyakarta, including the school's organization and governance, the learning quality, the student's competence, and the teaching competencies. Data from these four aspects can be seen in Fig 1.

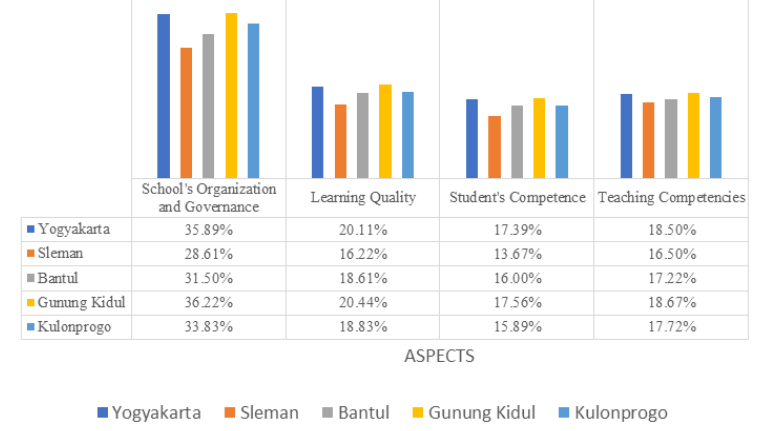

Figure 1 Mean score of the Quality of Education in VSSs

Figure 1 shows that in the school's organization and governance aspect, Gunung Kidul regency occupies the first position with an average score of 36.22, while the last position is occupied by Sleman Regency with an average score of 28.61. In the aspect of learning quality,
Gunung Kidul Regency occupies the first position with an average score of 20.44 while the last position is occupied by Sleman Regency with an average score of 16.22. In the aspect of student competence, Gunung Kidul Regency occupies the first position with an average score of 17.56 while the last position is occupied by Sleman Regency with an average score of 13.67. In terms of teaching competencies, Gunung Kidul Regency occupies the first position with an average score of 18.67 while the last position is occupied by Sleman Regency with an average score of 16.5. Figure 1 also provides information that the aspect of school organization and governance is the aspect that has the highest average score compared to other aspects and that Gunung Kidul Regency has the highest average score of all aspects compared to the Regency in the Special Region of Yogyakarta.

\subsection{Categorization of the Quality of Education in Vocational Secondary Schools}

The category of quality of education at the Vocational Secondary School level in the Special Region of Yogyakarta can be seen in Fig 2.

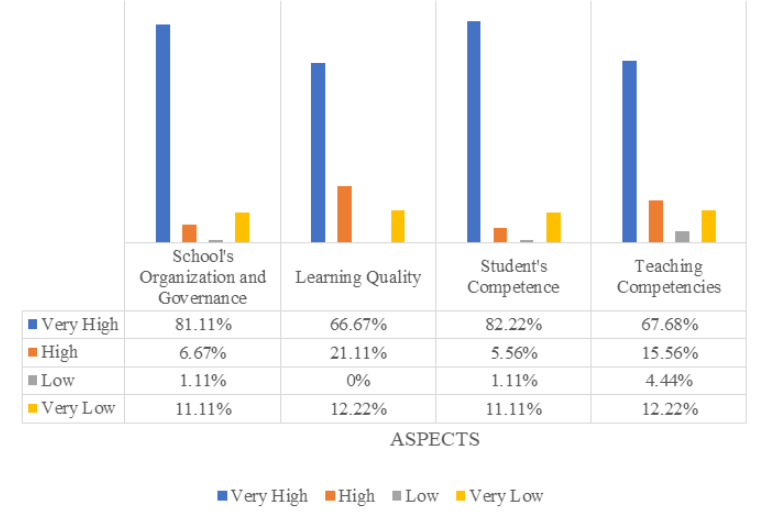

Figure 2 Category of the Quality of Education in VSSs

Figure 2 informs that all aspects are in the very high category but among the four aspects, the student competence aspect occupies the highest position with a percentage of $82.22 \%$.

\subsection{The Results of the Analysis of the Differences in Edu-cation Quality Test in Vocational Secondary Schools}

Before analysis using the Manova test, a prerequisite test was carried out consisting of a normality test and a data homogeneity test. The assumption of the dependent variable with multivariate normal distribution is illustrated by the scatter-plot correlation between the Mahalanobis distance variable from the multilingual evaluation variable and the qi variable (chi-square value) as shown in Fig 3. 


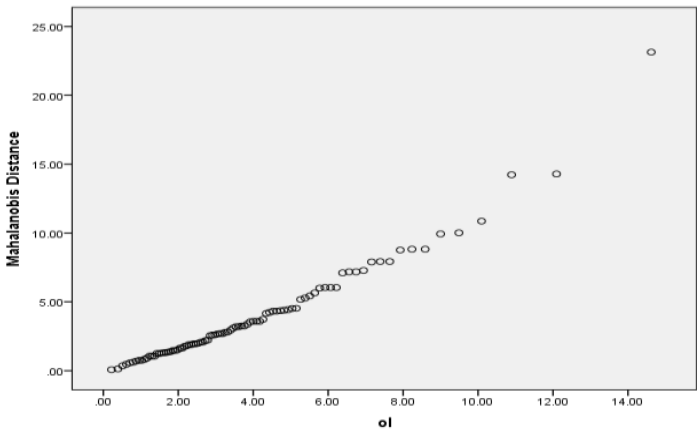

Figure 3 Scatter Plot Normality Test

In addition, it is known that the correlation coefficient obtained is 0.977 which indicates a high correlation coefficient with a Sig value $<0.05$, so there is a significant correlation, and the data are normally distributed multivariate. Besides, in the homogeneity test, the Box's Test obtained a sig value $0.000<0.5$ so that simultaneously testing the covariance equation between variables shows that the covariance between variables is not equivalent. Levene's test of variance in each particular variable, showed that the variance in each variable is not equivalent. However, the homogeneity of the test is not an absolute prerequisite test for using ANOVA. This test adds information about the results of data analysis and considerations in conducting Post Hoc tests using Games-Howell.

\subsubsection{Manova Test}

Based on the simultaneous analysis of Manova using Roy's Largest Root method, a significance value of $0.000<0.05$ was obtained, which means that there are significant differences in the quality of education at VSS level from various regencies in Special Region of Yogyakarta. The difference in the quality of education at VSS level in every aspect, described in Table 1.

Table 1. Tests of Between Subjects Effects

\begin{tabular}{|l|l|l|l|}
\hline Aspect & F & Sig & $\begin{array}{l}\text { Partial Eta } \\
\text { Square }\end{array}$ \\
\hline $\begin{array}{l}\text { School's } \\
\text { Organization and } \\
\text { Governance }\end{array}$ & 2.520 & .047 & .106 \\
\hline Learning Quality & 2.172 & .079 & .093 \\
\hline $\begin{array}{l}\text { Student's } \\
\text { Competence }\end{array}$ & 2.590 & .042 & .109 \\
\hline $\begin{array}{l}\text { Teaching } \\
\text { Competence }\end{array}$ & .806 & .525 & .037 \\
\hline
\end{tabular}

Table 1 shows that each aspect of the school's organization and governance, the learning quality, the student's competency, and the teaching competencies has impact of $10.6 \%, 9.3 \%, 10.9 \%$, and $3.7 \%$ on improving the quality of education at the VSS level in each regency in Special Region of Yogyakarta. The rest of the aspects may be influenced by other aspects that are not be focused in this study.

Manova's analysis shows the quality of education at the VSS level in each regency of the Special Region of Yogyakarta. Based on the post hoc analysis using Games-Howell's method shows, that Gunung Kidul Regency was in the first rank in the aspects of School's Organization and Governance, Learning Quality, and Teaching Competencies, followed by other regencies in sequence as follows: Kulonprogo, Bantul, and Sleman. Meanwhile, in the Student's Competence aspect, the first rank is occupied by Gunung Kidul Regency which is then followed by Yogyakarta City, Regency of Bantul, Kulonprogo, and Sleman respectively

\subsection{Discussion}

The enrollment zoning system aims to provide equity and equality distribution of education in various regencies in Indonesia. The zoning system exists to create equality between schools in their roles and duties so all schools in Indonesia are equal and there is no difference between favorite schools and ordinary schools. With this equal distribution, each regency will has experience educational services with a decent number of students, so it will be easier for the government to distribute educational facilities and infrastructure [20]. With the new policy, the government must be fair in facilitating each school with the hope that the quality of schools can be improved related to the school's goals. Besides that, educational staffs must also be professional in dealing with this new policy, so that a professional education personnel also contribute in increasing the quality of each school education units.

The quality of education can be seen from a reflection on performing the enrollment zoning system. Based on the results of the study, there were differences in the quality of education at the VSS level in each regency in Special Region of Yogyakarta. The impact of the enrollment zoning system in terms of the school's organization and governance aspect has an influence of $10.6 \%$ on the quality of education at the VSS level in each regency in. The school's organization and governance is the ability of an education unit or a school to manage in carrying on educational activities in its regency. Based on this aspect, it only contributes $10.6 \%$, which indicates that this aspect has an important role in improving the quality of education at VSS level in all regencies. This aspect includes academic service management and leadership that has several sub aspects include planning, organizing, providing services to service recipients monitored by a school, a quality of learning facilities in the form of the availability of adequate facilities and infrastructure that support learning activities in schools, and a quality assurance which means an integrated process that regulates all 
activities to ensure and improve the quality of education in schools [21]. In its implementation, this aspect and its sub aspects is carried out by the Enrollment Zoning System's committee supported by the existing facilities at each school. All members of the committee performed according to their duties and functions and obey the school's rules and support all provisions.

The impact of the enrollment zoning system can be viewed from the Learning Quality aspect that has an effect of $9.3 \%$ on the quality of education at VSS level in each regency in Special Region of Yogyakarta. The Learning Quality aspect means an ability of a school to manage and ensure the quality of learning process in each class. Thus, it only contributes $9.3 \%$, this aspect is viewed in two sub aspects which include the usage of contemporary methods and media learning, and the teacher's attitude in the learning process. The usage of contemporary methods and media learning is an ability of teachers to utilize various kinds of learning methods that can stimulate students' curiosity about the material, interest in learning, and students' motivation to learn. Teacher's attitude in the learning process is an ability of teachers to communicate well to students during the learning process [22]. This aspect has contributed 9.3\% which means it is quite small in improving the quality of education at VSS level. The effect of the enrollment zoning system in terms of student's competency aspect has an influence of $10.9 \%$ on the quality of education at VSS level in each regency. This aspect refers to academic achievement and non academic achievement. Academic achievement means a student's learning outcomes academically in classroom in terms of cognitive, psychomotor, and affective domains [23]. Non academic achievements are student's participation in extracurricular activities and regional, national and international level championships [7]. This aspect has contributed $10.9 \%$ which means it plays a quite role in increasing the quality of education at VSS level.

The influence of the enrollment zoning system in terms of Teaching Competencies aspect has contributed of $3.7 \%$ on the quality of education at VSS in each regency in the Special Region of Yogyakarta. This aspect is based on sub aspects of academic achievement and non academic achievement of teachers as part of their duties. Academic achievement means teachers' involvement in some academic activities, such as scientific forums, publications, and innovation works. The non academic achievements refer to teachers' participation in creative work competitions, creative works competitions, and professional organizations [24]. This aspect has contributed $3.7 \%$ which implies that this aspect has less role in performing the quality of education at VSS level. This result can be understood when the Covid 19 pandemic still hit Indonesia, the enrollment zoning system policy was no longer implemented optimally based on existing policies so it became one of limitations of this study.

\section{CONCLUSION}

This study shows that there are differences in the quality of education at VSS level in each regency in Special Region of Yogyakarta. The results of the study show that there are significant impacts of the enrollment zoning system on the learning quality at VSSs in Special Region of Yogyakarta in terms of four aspects with the order of each aspect as follows: $10.9 \%$ on the student's competency aspect, $10.6 \%$ on the school's organization and governance aspect, $9.3 \%$ on the learning quality aspect, and $3.7 \%$ on teaching competencies aspect. In general, at VSS level in each regency can be included in the very high category for all aspects. In addition, Gunungkidul Regency is the area that has the highest education quality score for all aspects. The results of this study can provide recommendations for further in depth study related to the teaching competence aspect that has the lowest impact and does not differ significantly among VSSs in applying the enrollment zoning system policy.

\section{AUTHORS' CONTRIBUTIONS}

The first and second Authors are in charge of writing the theory, while the third author is in charge of compiling the entire article.

\section{ACKNOWLEDGMENTS}

We would like to thank Universitas Negeri Yogyakarta for providing research grants that allowed this study to be completed.

\section{REFERENCES}

[1] S. B. Raharjo, Evaluasi Trend Kualitas Pendidikan di Indonesia, J. Penelit. Dan Eval. Pendidik., vol. 16, no. 2, pp. 511-532, Jan. 2013, DOI: https://doi.org/10.21831/pep.v16i2.1129.

[2] L. Hakim, Pemerataan Akses Pendidikan Bagi Rakyat sesuai dengan Amanat Undang-Undang Nomor 20 Tahun 2003 Tentang Sistem Pendidikan Nasional, EduTech J. Ilmu Pendidik. Dan Ilmu Sos., vol. 2, no. 1, pp. 53-64, 2016, DOI: https://doi.org/10.30596/edutech.v2i1.575.

[3] C. I. R. Marsiti, Upaya peningkatan mutu pendidikan sekolah menengah kejuruan melalui pengembangan profesionalisme guru, J. Pendidik. Vokasi, vol. 1, no. 1, pp. 157-168, Feb. 2011, DOI: https://doi.org/10.21831/jpv.v1i1.5810.

[4] I. M. Candiasa, Pemerataan dan Peningkatan Mutu Pendidikan Melalui Komunitas Guru Online, JST J. Sains Dan Teknol., vol. 2, no. 1, pp. 118-127, Apr. 2013, DOI: https://doi.org/10.23887/jstundiksha.v1i1.1417.

[5] T. J. V. Aristo, Analisis permasalahan pemerataan pendidikan di Kabupaten Sintang, J. Akuntabilitas 
Manaj. Pendidik., vol. 7, no. 1, pp. 25-34, Apr. 2019,

DOI:https://doi.org/10.21831/amp.v7i1.10923.

[6] A. K. Agnihotri, Quality in Primary and Secondary Education, Int. Sch. Res. J., vol. 4, no. 21, pp. 4878-4884, 2017. https://www.academia.edu/ $33375788 /$

\section{QUALITY_IN_PRIMARY_AND_SECONDARY} EDUCATION

[7] E. Gindo, C. Anagaw, and S. Sapo, Provision of Quality Education in Secondary Schools: An Investigation of Factors, vol. 7, no. 5, pp. 314-333, Jun. 2020 ,

DOI: https://doi.org/10.5281/ZENODO.3880450.

[8] G. of H. Education \& Literacy Departement, Sindh Education Sector Plan. India: Education \& Literacy Departement, Goverment of Hindi, 2019.

[9] M. R. Spruit and T. Adriana, "Quantifying Education Quality in Secondary Schools," Int. J. Knowl. Soc. Res., vol. 6, no. 1, pp. 55-86, Jan. 2015 , DOI: https://doi.org/10.4018/IJKSR.2015010104.

[10] G. I. Pradewi and R. Rukiyati, Kebijakan Sistem Zonasi dalam Perspektif Pendidikan, J. Manaj. Dan Supervisi Pendidik., vol. 4, no. 1, pp. 28-34, Nov. 2019, DOI: https://doi.org/10.17977/um025v4i12019p028.

[11] M. R. S. Ahmad, Sistem Penerimaan Peserta Didik Baru Jalur Zonasi Tahun 2018 di SMAN 21 Makassar, J. Has. Pemikir. Penelit. Dan Pengemb. Keilmuan Sosiol. Pendidik., vol. 7, no. 2, pp. 3338, 2020 , DOI: https://doi.org/10.26858/sosialisasi.v0i1.14355.

[12] D. C. S. Ishak, Evaluasi Kebijakan Sistem Zonasi Dalam Seleksi Penerimaan Peserta Didik Baru (PPDB) Tingkat Sekolah Menengah Atas di Kota Pekanbaru, Nakhoda J. Ilmu Pemerintah., vol. 18, no. 2, pp. 92-103, Apr. 2020, DOI: https://doi.org/10.35967/jipn.v18i2.7829.

[13] D. M. Ula and I. Lestari, Dampak Sistem Zonasi Bagi Sekolah Menengah Pertama, Briliant J. Ris. Dan Konseptual, vol. 5, no. 1, pp. 10-18, Feb. 2020,

DOI: https://doi.org/10.28926/briliant.v5i1.375.

[14] S. V. Mulyani, Tobari, and Houtman, Manajemen Pelaksanaan Penerimaan Peserta Didik Baru Sistem Zonasi, Jambura J. Educ. Manag., vol. 1, no. 2, pp. 71-84, Aug. 2020, DOI: https://doi.org/10.37411/jjem.v1i2.162.

[15] D. Purwanti, I. Irawati, and J. Adiwisastra, Efektivitas Kebijakan Penerimaan Peserta Didik Baru Sistem Zonasi Bagi Siswa Rawan Melanjutkan Pendidikan, Din. J. Ilm. Ilmu Adm.
Negara, vol. 5, no. 4, pp. 1-7, 2018, DOI: http://dx.doi.org/10.25157/dinamika.v5i4.1737.

[16] H. Hasbulah and S. Anam, Evaluasi Kebijakan Sistem Zonasi dalam Penerimaan Peserta Didik Baru (Ppdb) di Tingkat Sekolah Menengah Pertama Negeri (SMPN) di Kabupaten Pamekasan," REFORMASI, vol. 9, no. 2, pp. 112 122, Sep. 2019, DOI: https://doi.org/10.33366/rfr.v9i2.1413.

[17] D. Purwanti, I. Irawati, J. Adiwisastra, and H. Bekti, "Implementasi Kebijakan Penerimaan Peserta Didik Baru Berdasarkan Sistem Zonasi di Kota Bandung," J. GOVERNANSI, vol. 5, no. 1, pp. 12-23, Apr. 2019, DOI: https://doi.org/10.30997/jgs.v5i1.1699.

[18] S. Munadi, S. Hadi, and H. Retnawati, "Evaluasi Zonasi di Provinsi Yogyakarta, Indonesia.” LPPM UNY, 2020. [Online]. Available: https://simppm. lppm.uny.ac.id/data-publik/ download- abstrak/ SzhzMmN6R3N1RVZ sZFZkN0JRUzFSQT09

[19] R. T. Widyastuti, "Dampak Pemberlakuan Sistem Zonasi Terhadap Mutu Sekolah dan Peserta Didik," EDUSAINTEK J. Pendidik. SAINS DAN Teknol., vol. 7, no. 1, pp. 11-19, May 2020, DOI: https://doi.org/10.47668/edusaintek.v7i1.46.

[20] E. Saharuddin and M. S. Khakim, "Implementasi Kebijakan Sistem Zonasi Dalam Penerimaan Peserta Didik Baru Pada Tingkat Sma Di Daerah Istimewa Yogyakarta," Din. J. Ilm. Ilmu Adm. Negara, vol. 7, no. 3, pp. 424-438, 2020, DOI: http://dx.doi.org/10.25157/dinamika.v7i3.4226.

[21] O. A. Ojo and E. O. Adu, "Transformation of teaching quality in secondary school education: Teachers' conception," Perspect. Educ., vol. 35, no. 2, pp. 60-72, 2017, DOI: https://doi.org/10.18820/2519593X/pie.v35i2.5.

[22] D. Kirikkaleli, H. M. Ertugrul, A. Sari, A. Ozun, and H. Kiral, "Quality of Education and Technological Readiness: Bootstrap Panel Causality Analysis for Northern European Countries," Scand. J. Educ. Res., vol. 65, no. 2, pp. 276-287, Feb. 2021, DOI: https://doi.org/10.1080/00313831.2019.1705892.

[23] C. Jain and N. Prasad, Quality of Secondary Education in India. Singapore: Springer Singapore, 2018. DOI: https://doi.org/10.1007/978-981-104929-3.

[24] G. A. Gobena, "Factors Affecting In-Service Teachers' Motivation: Its Implication to Quality of Education," Int. J. Instr., vol. 11, no. 3, pp. 163178, Jul. 2018, DOI: https://doi.org/10.12973 /iji.2018.11312a. 